\title{
КОНСТИТУЦИОННОЕ ПРАВО
}

\author{
УДК 342.734
}

DOI: $10.18287 / 2542-047 \mathrm{X}-2018-4-1-29-37$

C. A. Ocempoв*

\section{ФУНКЦИИ ПРЕЗИДЕНТСКОЙ ВЛАСТИ В РОССИЙСКОЙ ФЕДЕРАЦИИ}

\begin{abstract}
В статье рассматриваются функции Президента Российской Федерации в системе публичной власти, а также предлагается классификация данных функций. Выделена, во-первых, традиционная представительская функция Президента Российской Федерации, во-вторых, специфическая функция главы Российского государства, связанная с осуществлением координации деятельности органов публичной власти и арбитража при возникновении политических конфликтов. В-третьих, выделяется функция государственного управления, осуществляемая специфическими, присущими президентской власти методами. При этом предпринята попытка разграничить исполнительную и президентскую власть в процессе осуществления государственного управления с указанием на то, что к конституционным функциям президентской власти относится модерирование исполнительной власти. На основе анализа функций автор статьи приходит к выводу о самостоятельной политико-правовой природе функций президентской власти, которые несвойственны иным ветвям государственной власти.
\end{abstract}

Ключевые слова: государственная власть, Президент Российской Федерации, президентская власть, функции президентской власти.

Выделение самостоятельной ветви президентской власти в Российской Федерации основывается на фактически сформированной в конституционных параметрах самостоятельной функциональной нагрузке, выполняемой Президентом Российской Федерации в системе государственного управления.

Ветвь государственной власти представляет собой организационно-юридическую трансформацию определенной функции государственного аппарата по управлению в обществе [1, с. 235]. По мнению В. Е. Чиркина, каждая ветвь государственной власти в ее структуре имеет особую ролевую функцию по государственному управлению [2, с. 84]. В этой связи анализ внешних проявлений ветви президентской власти предполагает и выявление особых функций президентской власти в системе власти, то есть ценностно-функционального содержания президентской власти.

Необходимо отметить, что наименование «классических ветвей государственной власти» указывает, в первую очередь на функциональную составляющую их деятельности - законодательную, исполнительную (или исполнительно-распорядительную) и судебную [2, с. 82]. Наименование президентской власти (подобное наименование в настоящее время является наиболее часто используемым в научной литературе $[1$, с. $240 ; 3$, с. 326 ; 4 , с. 252 ; 5 , с. 473 ; 6 , с. 264 ;
7, с. $154 ; 8$, с. 11]) в этом плане производно от наименования государственной должности Российской Федерации и не раскрывает содержательно данное направление государственного властвования. Каково же функциональное содержание президентской власти, отличающее ее от иных ветвей государственной власти и придающее президентской власти самостоятельную значимую роль в системе государственного управления?

Как правило, под функцией понимается деятельность, роль объекта в рамках некоторой системы, к которой он принадлежит [9, с. 890]. В связи с этим вопрос о выделении функций ветви государственной власти на первый взгляд может показаться достаточно простым. Однако более тщательное рассмотрение данного вопроса приводит к различным затруднениям объективного и субъективного характера. Что касается вычленения и классификации функций президентской власти в Российской Федерации, то данный вопрос представляется весьма затруднительным по ряду причин, в том числе ввиду отсутствия нормативной категории функции применительно к президентской власти, неопределенности соотношения функций с конкретными полномочиями главы государства, а также участия Президента Российской Федерации в отдельных случаях в осуществлении функций иных институтов публичной власти.

* (C) Осетров С. А., 2018

Осетров Сергей Анатольевич (sergey-lupus@mail.ru), кафедра государственного и административного права, Самарский национальный исследовательский университет имени академика С. П. Королева, 443086, Российская Федерация, г. Самара, Московское шоссе, 34 . 
Все это объясняет отсутствие сложившейся доктринальной классификации функций президентской власти в Российской Федерации. У каждого исследователя президентской власти можно обнаружить собственный подход к пониманию президентской власти в содержательном плане.

К примеру, Ю. А. Дмитриев, А. М. Николаев, указывая на становление самостоятельной президентской ветви власти в Российской Федерации, анализируют ее содержание, ограничиваясь взаимоотношениями с иными ветвями власти [10, c. $356-430]$.

В. Н. Суворов, не проводя жестких границ различия между функциями и полномочиями, выделяет следующие направления деятельности Президента России: 1) традиционные властные полномочия главы государства; 2) функции гаранта и арбитра в системе власти; 3) осуществление исполнительной власти; 4) участие в осуществлении законодательной власти; 5) решение или участие в решении вопросов формирования судебных органов, определении их кадрового состава [11, с. 22].

Е. И. Козлова к функциям Президента относит гарантирование Конституции, прав и свобод человека и гражданина, обеспечение целостности государства, определение основных направлений внутренней и внешней политики, представительство России внутри страны и в международных отношениях. Помимо этого, в качестве важной конституционной функции Президента выделяется обеспечение осуществления полномочий федеральной государственной власти на всей территории Российской Федерации [3, с. 379-383, 388].

Е. И. Колюшин утверждает, что в систему основных функций Президента Российской Федерации входят следующие направления его деятельности: определение основных направлений внутренней и внешней политики, государственное управление, участие в законодательном процессе, консолидация общества и государства, представительство государства $[4$, с. 252$]$.

В монографии О. Е. Кутафина обращается внимание, что основной характеристикой статуса Президента России выступает то, что он сочетает в себе два качества: органа государственной власти и должностного лица. При этом как орган государства он выполняет возложенные на него Конституцией России и законами функции, а в качестве высшего должностного лица он выполняет различные представительские функции. В обобщенной форме функции главы российского государства сформулированы в статье 80 Конституции Российской Федерации и включают в себя функции гаранта Конституции России, гаранта прав и свобод человека и гражданина, охраны суверенитета Российской Федерации, ее независимости и государственной целостности, функцию обеспечения согласованного функционирования и взаимодействия органов государственной власти, определение основных на- правлений внешней и внутренней политики, а также представительские функции [12, с. 321-340].

Таким образом, в науке конституционного права Российской Федерации до настоящего времени не сложилось единых целостных представлений о функциональном содержании президентской власти. Однако большинство конституционалистов склоняется к мысли о том, что ключевой в плане детерминации функций президентской власти является именно статья 80 Конституции Российской Федерации. Разделяя в целом данный подход, полагаем возможным отметить, что Президентом Российской Федерации осуществляется значительное количество самых разнообразных функций, которые могут быть структурированы следующим образом.

Во-первых, традиционной функцией главы государства и президентской власти выступает представительская функция. В соответствии с частью 4 статьи 80 Конституции Российской Федерации Президент Российской Федерации как глава государства представляет Российскую Федерацию внутри страны и в международных отношениях.

Во-вторых, гораздо более насыщенной выступает деятельность президентской власти в рамках исполнения своих специфических функций, которые в науке права обозначаются следующим образом. Так, Г. В. Дегтев выделяет три специфические функции президентской власти - гарантийная, арбитражно-интегративная и контрольная. Гарантийная функция при этом заключается в том, что Президент Российской Федерации - гарант Конституции, суверенитета, независимости и территориальной целостности государства, прав и свобод человека и гражданина. Арбитражно-интегративная функция объясняется необходимостью обеспечения согласованного взаимодействия, стабильного сотрудничества и единства всех ветвей государственной власти. Контрольная функция реализуется посредством отчетности Правительства перед Президентом Российской Федерации, прямого подчинения ряда министерств и ведомств главе Российского государства, а также отмены Президентом Российской Федерации нормативных актов Правительства России. В отношении парламента контроль осуществляется в рамках процедуры подписания законов, [13, с. 156-158], реализации права вето. Аналогичных взглядов придерживается и С. Г. Паречина [8, c. 13-15]. Следует отметить, что схожие функции президентской власти выделяются и французскими конституционалистами, исследующими конституционные начала государственной власти во Франции, конституционный опыт которой был активно использован и при разработке Конституции Российской Федерации. Так, Ф. Ардан указывает, что Президент Франции выполняет функции хранителя Конституции, арбитра и гаранта [14, с. 61-62].

В. А. Лебедев и В. В. Киреев отмечают, что Президент Российской Федерации в российской модели разделения власти выполняет функции ди- 
рижера-арбитра, выступая при этом координатором всей преобразовательной деятельности государства. В дополнение к этому Президент Российской Федерации гарантирует стабильность политической системы [15, с. 132].

Е. И. Козлова утверждает, что принцип разделения власти предполагает наличие такого органа, который обеспечивает согласованное функционирование и взаимодействие органов государственной власти, возлагаемое на Президента России [3, с. 378-383].

Часть ученых отстаивает идею особых интегративных функций президентской власти. В целом их позиция заключается в том, что Президент Российской Федерации воплощает единство государственной власти, обеспечивает конституционноправовые механизмы и содержание генетического, структурного и функционального типов целостности государства [16, с. $248 ; 17$, с. 8]. Профессор Б. С. Эбзеев, обращая внимание на доминирование интеграционной функции президентской власти, также отмечает наличие у главы Российского государства координационной функции, посреднической (арбитражной) функции, функции политического резерва, гарантийной функции, функции правового резерва, государственно-нотариальной функции [18, с. 212-215].

М. А. Краснов обращает внимание на то, что Президент Российской Федерации является институтом, предназначенным, во-первых, для традиционного олицетворения завершенности государственной конструкции, во-вторых, для принятия оперативных мер по защите конституционного строя, государственного суверенитета, целостности страны, а, в-третьих, что особенно важно, для независимого политического арбитража. По его мнению, статус главы государства предполагает выполнение фундаментальной роли хранителя государственности и стабилизатора политической системы. При этом модус хранителя государственности выражается в его функциях выступать в качестве гаранта Конституции России, прав и свобод человека и гражданина, принимать меры по охране суверенитета Российской Федерации, ее независимости и государственной целостности, а также представлять Российскую Федерацию внутри страны и в международных отношениях. Модус же стабилизатора политической системы отражается главным образом в обеспечении согласованного функционирования и взаимодействия органов государственной власти [19, с. 17-20; 20, с. 68-82]. Правда, профессор М. А. Краснов также указывает и на опасность подобного функционального статуса главы государства, позитивная реализация которого возможна в условиях, когда целью существования института президентства стали бы исключительно цели и задачи по охране, защите и в случае необходимости по восстановлению конституционного строя. Только в этом случае, по мысли ученого, можно говорить о подлинно нейтральной власти, оберегающей конституционное государство от катаклизмов [21, с. 69].

В. И. Кайнов утверждает, что институт президентства выступает в качестве гаранта стабильности развития общества, действенного инструмента осуществления основных прав и свобод. Именно глава государства способствует сохранению преемственности власти, поддержанию правопорядка в обществе и соблюдению Конституции [22, с. 12].

Таким образом, несмотря на терминологические различия в представленных исследованиях, в науке права сформированы достаточно глубокие представления о специальных, не присущих иным ветвям власти, функциях президентской власти.

Однако на этом функции президентской власти не заканчиваются. Третий блок функций президентской власти, реализуемых главой российского государства - государственное управление в узком смысле. Президент Российской Федерации В. В. Путин достаточно точно обозначил данное направление деятельности Президента Российской Федерации. Так, в послании Президента Российской Федерации Федеральному Собранию от 11.07.2000 отмечается, что только действующий глава государства вправе ставить перед органами власти программные задачи и только у него есть реальная возможность организовать их эффективное выполнение [23]. Наиболее последовательно и обстоятельно соответствующее функциональное содержание президентской власти описал И. Т. Беспалый. По мнению ученого, именно инициативная распорядительная властная деятельность Президента Российской Федерации является основной частью его государственно-властной деятельности. Она выражается в следующих формах: Президент Российской Федерации обращается к Федеральному Собранию Российской Федерации с ежегодными посланиями о положении в стране, об основных направлениях внешней и внутренней политики государства (статья 84 Конституции России); Президенту Российской Федерации принадлежит право законодательной инициативы (статья 84 Конституции России); он непосредственно руководит работой Правительства Российской Федерации (пункт «б» статьи 83 Конституции Российской Федерации) при том условии, что президентская и исполнительная власти отделяются; глава государства издает многочисленные указы как в порядке выполнения федеральных законов, так и по собственной инициативе в рамках принадлежащих главе государства полномочий [24, с. 156-158]. В рамках данного функционального направления деятельности президентской власти наиболее отчетливо проявляются функциональные отличия президентской власти от власти исполнительной.

Профессор С. А. Авакьян в рамках детерминации видов властных функций определил, что функция руководства общественно-политическими, народно-хозяйственными и социальными процессами наиболее свойственна применительно к Рос- 
сии Президенту Российской Федерации [25, с. 72], а функция управления, предполагающая оперативное, повседневное рассмотрение вопросов хозяйственной жизни, более характерна для органов исполнительной власти.

Исполнительная власть, даже исходя из семантики данного термина, призвана в большей степени исполнять волевые проявления иных властей. Президентская власть в данном смысле, осуществляемая в рамках Конституции и действующего законодательства, реализует прежде всего собственную волю. Иные институты публичной власти не вправе давать поручения Президенту. Единственное исключение представляет Федеральное Собрание Российской Федерации, определяющее параметры функционирования всей системы публичной власти в рамках законодательной деятельности. Вместе с тем роль Президента в данном случае также не сводится к техническому исполнению предписаний федерального законодателя. Прежде всего необходимо отметить, что Конституция Российской Федерации в принципе не предусматривает принятия специального законодательного акта, регламентирующего статус главы Российского государства. Более того, в соответствии со статьей 107 Конституции Российской Федерации принятые федеральные законы в течение пяти дней направляются Президенту Российской Федерации для подписания и обнародования. При этом глава государства вправе отклонить их. Таким образом, Президент Российской Федерации не является статистом в законодательном процессе и имеет действенные правовые механизмы влияния на соответствующий процесс. Не случайны в связи с этим и те положения федеральных законов, в которых Президенту именно предлагают, а Правительству Российской Федерации поручают осуществить определенные действия (статья 41 Федерального конституционного закона «О чрезвычайном положении» [26], статья 10 Федерального конституционного закона «О государственном гимне Российской Федерации» [27] и др.).

Деятельность Президента России в системе государственного управления в большей степени направлена на стимулирование деятельности иных институтов публичной власти. Для этого глава Российского государства подает необходимые «импульсы» для работы государственного механизма в том или ином направлении, а также распоряжается ресурсами иных государственных органов, прежде всего органов исполнительной власти [28, с. 129]. То, что именно президентская власть становится двигателем реформ, характерно не только для Российской Федерации. В США именно президенты становились главными инициаторами проведения крупномасштабных реформ американского общества: «Новый курс» Ф. Рузвельта, «Великое общество» Л. Джонсона, «Рейгономика» [8, с. 34]. Указанный пример США в данном случае не совсем оптимален ввиду существующей в США президент- ской формы правления. Вместе с тем он демонстрирует особую роль Президента США именно как главы государства, лидера нации в вопросах государственного управления.

Все это свидетельствует о том, что президентская и исполнительная власть не тождественны. При этом линия разграничения между президентской и исполнительной властью лежит не только в предметно-отраслевой плоскости (президент руководит или полностью контролирует административно-политические отрасли деятельности исполнительного аппарата, а правительство несет ответственность за управление экономикой и социально-культурной сферой), как утверждают отдельные исследователи, обосновывающие идею бицефальной исполнительной власти (дуализма исполнительной власти) [29, с. 13]. Смысл различий между указанными ветвями - в содержании осуществляемой власти. Президент и правительство функционально разноуровневые и конституционно самостоятельные институты власти [30].

В то же время не стоит отрицать и того факта, что президентская и исполнительная власть в Российской Федерации весьма тесно связаны. При этом в отдельные периоды их совместного функционирования политическая конъюнктура складывалась таким образом, что исполнительная власть могла быть охарактеризована как специфическая форма власти президентской [31, с. 101]. Нельзя не согласиться в данном случае с профессором М. А. Красновым, указывающим на наличие элементов внутреннего конфликта российской властной конструкции, заключающегося в фактическом и юридическом совмещении главой Российского государства функций хранителя конституционного строя и функции партийного деятеля, связанной с реализацией отраслевой политики и полномочий по единоличному формированию Правительства Российской Федерации [32, с. 40].

Полагаем, однако, что подобная практика «подмены исполнительной власти властью президентской» не соответствует конституционной модели функционирования государственной власти. Конституция не детерминирует главу государства в качестве главы исполнительной власти. В то же время анализ Конституции Российской Федерации в части взаимоотношений Президента Российской Федерации и институтов исполнительной власти позволяет выделить дополнительную функцию президентской власти - определять параметры исполнительной власти и гарантировать ее осуществление в рамках соответствующих параметров, а также модерировать (умерять, сдерживать) [33, с. 318] еe, то есть удерживать в разумных пределах.

Что касается определения параметров осуществления исполнительной власти и гарантирования ее осуществления в рамках соответствующих параметров, то глава Российского государства в соответствии со статьей 80 Конституции Российской Федерации определяет основные направления внешней и 
внутренней политики государства, обязательные для исполнения Правительством Российской Федерации. Послания Президента Российской Федерации Федеральному Собранию, как правило, содержат значительный перечень поручений Правительству Российской Федерации. Именно глава государства осуществляет назначение с согласия Государственной думы председателя Правительства Российской Федерации, а также по предложению председателя Правительства Российской Федерации назначает на должность заместителей председателя Правительства Российской Федерации и федеральных министров. В соответствии со статьей 112 Конституции Российской Федерации Президент Российской Федерации утверждает структуру федеральных органов исполнительной власти, а также, исходя из постановления Конституционного Суда Российской Федерации от 27.11.1999 № 2-П «По делу о толковании статей 71 (пункт «Г»), 76 (часть 1) и 112 (часть 1) Конституции Российской Федерации» [34], регулирует вопросы системы федеральных органов исполнительной власти в части, не урегулированной законодателем. В дополнение к этому статьей 113 Конституции России предусматривается, что председатель Правительства Российской Федерации определяет основные направления деятельности Правительства Российской Федерации и организует его работу в соответствии с указами Президента Российской Федерации. Данная норма, по сути, продублирована и в статье 115 Конституции, закрепляющей, что Правительство Российской Федерации издает постановления и распоряжения, в том числе на основании нормативных указов Президента Российской Федерации.

В отношении модерирования Президентом Российской Федерации деятельности Правительства Российской Федерации Конституция устанавливает следующие действенные механизмы. Глава Российского государства вправе председательствовать на заседаниях Правительства Российской Федерации. В данном случае важно обратить внимание на то, что в Конституции России используется именно термин «имеет право», то есть речь идет о том, что соответствующая деятельность для Президента Российской Федерации не является систематической. В этом контексте также видится и прерогатива Президента Российской Федерации принимать решение об отставке Правительства Российской Федерации, освобождении от должности заместителей председателя Правительства Российской Федерации и федеральных министров. В соответствии со статьей 115 Конституции Российской Федерации Президент Российской Федерации также вправе отменить постановления и распоряжения Правительства Российской Федерации в случае их противоречия Конституции Российской Федерации, федеральным законам и указам Президента Российской Федерации.

Таким образом, анализ Конституции Российской Федерации свидетельствует о том, что функ- ционально президентская и исполнительная власти скорее разведены. В то же время в действующем законодательстве этот вопрос не столь очевиден. Статья 32 Федерального конституционного закона «О Правительстве Российской Федерации» закрепляет, что Президент Российской Федерации в соответствии с Конституцией Российской Федерации, федеральными конституционными законами, федеральными законами руководит деятельностью федеральных органов исполнительной власти, ведающих вопросами обороны, безопасности, внутренних дел, юстиции, иностранных дел, предотвращения чрезвычайных ситуаций и ликвидации последствий стихийных бедствий, утверждает по представлению председателя Правительства Российской Федерации положения о них и назначает руководителей и заместителей руководителей этих органов, а также осуществляет иные полномочия как Верховный главнокомандующий Вооруженными силами Российской Федерации и председатель Совета Безопасности Российской Федерации. При этом Правительство Российской Федерации координирует деятельность соответствующих органов исполнительной власти.

Анализ статуса органов исполнительной власти свидетельствует о том, что они находятся в двойном подчинении (см., например, пункты 3, 4 Положения о Министерстве внутренних дел Российской Федерации, утвержденного Указом Президента Российской Федерации от 21.12.2016 № 699 [35], пункты 1, 7, 12 Положения о Министерстве юстиции Российской Федерации, утвержденного Указом Президента Российской Федерации от 13.10.2004 № 1313 [36], пункты 1, 2, 6, 8 Положения о Министерстве иностранных дел Российской Федерации, утвержденного Указом Президента Российской Федерации от 11.07.2004 № 865 [37]).

Профессор Л. А. Нудненко отмечает, что соотношение властных президентских полномочий, с одной стороны, и полномочий федерального Правительства - с другой, в совокупности позволяет говорить о дуалистической природе исполнительной власти в Российской Федерации. По ее мнению, особенностью осуществления исполнительной власти в Российской Федерации является своеобразное разделение труда между высшим коллегиальным органом исполнительной власти и Президентом России при доминировании последнего [38, с. 107].

В то же время руководство со стороны Президента России в отношении органов исполнительной власти осуществляется только в отношении органов, входящих в «силовой блок правительства» и осуществляется также в специфических формах, присущих именно президентской власти и несвойственных власти исполнительной. В частности, именно Президент Российской Федерации инициировал недавнюю реформу министерств «силового блока», в рамках которой была образована Федеральная служба войск национальной гвардии Российской Федерации (Указ Президен- 
та Российской Федерации от 05.04.2016 № 157 [39]). Названный Указ Президента Российской Федерации по своей правовой природе относится к «опережающему» нормотворчеству, что следует из преамбулы соответствующего правового акта, указывающей на его действие «впредь до принятия соответствующего федерального закона». При этом сам Президент РФ непосредственно не участвует в оперативно-исполнительской деятельности, которую осуществляют органы исполнительной власти [40, с. 114-115].

С учетом этого можно констатировать, что в современных конституционных параметрах президентская власть и исполнительная власть в России не тождественны. Президентская власть самостоятельна в организационном плане, а также имеет существенные функциональные особенности, отличающие ее от исполнительной власти.

\section{Библиографический список}

1. Хабриева Т. Я., Чиркин В. Е. Теория современной конституции. М.: Норма, 2005. 319 с.

2. Чиркин В. Е. Законодательная власть. М.: Норма, 2008. $335 \mathrm{c}$.

3. Козлова Е. И., Кутафин О. Е. Конституционное право России: учеб. 4-е изд., перераб. и доп. М.: ТК «Велби»; Изд-во «Проспект», 2008. 565 с.

4. Колюшин Е. И. Конституционное право России: курс лекций. М.: ОАО «Издательский Дом «Городец», 2006. $415 \mathrm{c}$.

5. Конституционное право России: учебник для студентов вузов / А. С. Прудников [и др.]; под ред. А. С. Прудникова, В. И. Авсеенко. 3-е изд., перераб. и доп. М.: ЮНИТИ-ДАНА, 2007. 767 с.

6. Венгеров А. Б. Теория государства и права: учеб. [для юрид. вузов]. 4-е изд., стер. М.: Омега-Л, 2007. 528 с.

7. Беспалый И. Т., Полянский В. В. Государственное право Российской Федерации: учебное пособие: в 2 ч. Часть II. 2-е изд., перераб. и доп. Самара: изд-во «Самарский университет», 2008. 539 с.

8. Паречина С. Г. Институт президентства: история и современность / под общ. ред. Е. В. Матусевича. Минск: ИСПИ, 2003. 163 с.

9. Большой энциклопедический словарь: философия, социология, религия, эзотеризм, политэкономия / гл. науч. ред. и сост. С. Ю. Солодовников. Минск: МФЦП, 2002. 1008 с.

10. Дмитриев Ю. А., Николаев А. М. Система государственной власти в России и мире: историко-правовая ретроспектива. М.: ООО «Профобразование», 2002. 839 с.

11. Суворов В. Н. Глава российского государства (правовой статус, положение в системе власти). М., 2000. $352 \mathrm{c}$.

12. Кутафин О. Е. Глава государства: монография. М.: Проспект, 2013. 560 с.

13. Дёгтев Г. В. Становление и развитие института президентства в России: теоретико-правовые и конституционные основы. М.: Юристъ, 2005. 237 с.
14. Ардан Филипп. Франция: государственная система: пер. с франц. М.: Юрид. лит., 1994. 176 с.

15. Лебедев В. А., Киреев В. В. Суверенная демократия: идеология-политика-право (теоретические аспекты). Челябинск: Челяб. гос. ун-т, 2008. 255 с.

16. Эбзеев Б. С., Краснорядцев С. Л., Левакин И. В., Радченко В. И. Государственное единство и целостность Российской Федерации (конституционно-правовые проблемы) / отв. ред. Б. С. Эбзеев. М.: ЗАО «Издательство «Экономика», 2005. 574 с.

17. Плеханова Л. Н. Президент Российской Федерации в системе органов правовой охраны Конституции Российской Федерации: дис. ... канд. юрид. наук. Томск, 2004. 261 с.

18. Эбзеев Б. С. Конституция, власть и свобода в России: Опыт синтетического исследования. М.: Проспект, 2014. 336 с.

19. Краснов М. А. Персоналистский режим в России: опыт институционального анализа. М.: Фонд «Либеральная миссия», 2006. 180 с.

20. Краснов М. А. Доктрина «подразумеваемых (скрытых) полномочий» главы государства в российской конституционно-правовой практике // Конституционный вестник. 2010. № 2(20).

21. Краснов М. А. «Нейтральная власть» Б. Констана и «Президентский арбитраж» Ш. Де Голля // Государство и право. 2017. № 6.

22. Кайнов В. И. Институт президентства: конституционно-правовой статус: дис. ... д-ра юрид. наук. СПб., 1999. 332 с.

23. Послание Президента Российской Федерации Федеральному Собранию «Какую Россию мы строим» // Российская газета. 2000. 11 июля.

24. Беспалый И. Т., Полянский В. В. Государственное право Российской Федерации: учебное пособие: в 2 ч. Часть II / Федеральное агентство по образованию. 2-е изд., перераб. и доп. Самара: Самарский университет, 2008. 539 с.

25. Современные проблемы организации публичной власти: монография / рук. авт. кол. и отв. ред. проф. С. А. Авакьян. М.: Юстицинформ, 2014. 596 с.

26. О чрезвычайном положении: федеральный конституционный закон от 30.05.2001 № 3-ФК3 // Собрание законодательства Российской Федерации. 2001. № 23. Ст. 2277.

27. О государственном гимне Российской Федерации: федеральный конституционный закон от 25.12.2000 № 3-ФК3 // Собрание законодательства Российской Федерации. 2000. № 52 (часть I). Ст. 5022.

28. Аккаева Х. А. Принцип разделения власти конституционная основа построения и функционирования государственного механизма в России: дис. ... канд. юрид. наук. СПб., 2005. 196 с.

29. Гаджи-Заде Э. А. Конституционные модели формы правления и институт президентства в странах СНГ: дис. ... канд. юрид. наук. Волгоград, 2005. 227 с.

30. Окуньков Л. А. Президент и Правительство (в механизме государственной власти) // Журнал российского права. 2001. № 2. 
31. Болдырева Р. С. Разделение властей: теоретико-правовые аспекты: дис. ... канд. юрид. наук. М., 1998. 164 c.

32. Краснов М. А. Искажение смысла российской Конституции - следствие несбалансированной системы власти // Конституционное право и политика: сб. материалов международной научной конференции / Юридический факультет МГУ имени М.В. Ломоносова. 28-30 марта 2012 года; отв. ред. проф. С. А. Авакьян. М.: Юрист, 2012. 800 с.

33. Словарь иностранных слов. 13-е изд., стереотип. М.: Рус. яз., 1986. 736 с.

34. По делу о толковании статей 71 (пункт «Г»), 76 (часть 1) и 112 (часть 1) Конституции Российской Федерации: постановление Конституционного Суда Российской Федерации от 27.11.1999 № 2-П // Собрание законодательства Российской Федерации. 1999. № 6. Ст. 866.

35. Положение о Министерстве внутренних дел Российской Федерации, утвержденное Указом Президента Российской Федерации от 21.12.2016 № 699 // Собрание законодательства Российской Федерации. 2016. № 52. Ст. 7614.

36. Положения о Министерстве юстиции Российской Федерации, утвержденное Указом Президента Российской Федерации от 13.10.2004 № 1313 // Собрание законодательства Российской Федерации. 2004. № 42. Ст. 4108.

37. Положение о Министерстве иностранных дел Российской Федерации, утвержденное Указом Президента Российской Федерации от 11.07.2004 № 865 // Собрание законодательства Российской Федерации. 2004. № 28. Ст. 2880.

38. Нудненко Л. А. Система исполнительной власти в Российской Федерации: проблемы правовой регламентации: монография. М.: Юрлитинформ, 2017. $320 \mathrm{c}$.

39. Указ Президента Российской Федерации от 05.04.2016 № 157 // Российская газета. 2016. 7 апреля.

40. Правительство Российской Федерации / под ред. Т. Я. Хабриевой. М.: Норма, 2005. 608 с.

\section{References}

1. Habrieva T. Ya., Chirkin V. E. Teoriia sovremennoi konstitutsii [Theory of contemporary constituion]. M.: Norma, 2005, 319 p. [in Russian].

2. Chirkin V. E. Zakonodatel'naia vlast' [Legislative power]. M.: Norma, 2008, 335 p. [in Russian].

3. Kozlova E. I., Kutafin O. E. Konstitutsionnoe pravo Rossii: ucheb. 4-e izd., pererab. i dop. [Constitutional law of Russia: textbook. 4th edition, revised and enlarged]. M.: TK «Velbi», Izd-vo «Prospekt», 2008, 565 p. [in Russian].

4. Kolushin E. I. Konstitutsionnoe pravo Rossii: Kurs lektsii [Constitutional law of Russia: Course of lectures]. M.: OAO «Izdatel'skii Dom «Gorodets», 2006, 415 p. [in Russian].

5. Konstitutsionnoe pravo Rossii: uchebnik dlia studentov vuzov A. S. Prudnikov [ i dr.]; pod red.
A. S. Prudnikova, V. I. Avseenko. 3-e izd., pererab. i dop. [Constitutional law of Russia: course book for students. A. S. Prudnikov [et al.]; A. S. Prudnikov, V. I. Avseenko (Eds.). 3rd edition, revised and enlarged]. M.: IuNITIDANA, 2007, 767 p. [in Russian].

6. Vengerov A. B. Teoriia gosudarstva i prava: ucheb. [dlia iurid. vuzov]. 4-e izd., ster. [Theory of state and law: textbook [for law schools]. 4th edition, stereotype]. M.: Omega-L, 2007, 528 p. [in Russian].

7. Bespaly I. T., Polyansky V. V.Gosudarstvennoe pravo Rossiiskoi Federatsii: uchebnoe posobie: v 2 ch. Chast' II. Federal'noe agentstvo po obrazovaniiu. 2-e izd., pererab. i dop. [State Law of the Russian Federation: in 2 parts. Part II. 2-nd edition, revised and enlarged]. Samara: izd-vo «Samarskii universitet», 2008, 539 p. [in Russian].

8. Parechina S. G. Institut prezidentstva: istoriia i sovremennost'. Pod obshch. red. E. V. Matusevicha [Institute of presidency: history and present. E. V. Matusevich (Ed.)]. Minsk: ISPI, 2003, 163 p. [in Russian].

9. Bol'shoi entsiklopedicheskii slovar': filosofiia, sotsiologiia, religiia, ezoterizm, politekonomiia. Glavn. nauch. red. i sost. S. Iu. Solodovnikov [Great encyclopedic dictionary: philosophy, sociology, religion, esoterism, political economy. Chief science editor and complier S. Yu. Solodovnikov]. Minsk: MFTsP, 2002, 1008 p. [in Russian].

10. Dmitriev U. A., Nikolaev A. M. Sistema gosudarstvennoi vlasti v Rossii i mire: istoriko-pravovaia retrospektiva [System of state power in Russia and in the world: historical and legal retrospective]. M.: OOO «Profobrazovanie», 2002, 839 p. [in Russian].

11. Suvorov V. N. Glava rossiiskogo gosudarstva (pravovoi status, polozhenie v sisteme vlasti) [The head of the Russian Federation (legal status, position in the system of power)]. M., 2000, 352 p. [in Russian].

12. Kutafin O. E. Glava gosudarstva: monografiia [The head of state: monography]. M.: Prospekt, 2013, 560 p. [in Russian].

13. Degtev G. V. Stanovlenie i razvitie instituta prezidentstva v Rossii: teoretiko-pravovye i konstitutsionnye osnovy [Forming and developing of the institute of the President of Russia: theoretical and legal and constitutional bases]. M.: Iurist", 2005, 237 p. [in Russian].

14. Ardan Philippe. Frantsiia: gosudarstvennaia sistema: per. s frants. [France: state system: transl. from French]. M.: Iurid. lit., 1994, 176 p. [in Russian].

15. Lebedev V. A., Kireev V. V. Suverennaia demokratiia: ideologiia-politika-pravo (teoreticheskie aspekty) [Sovereign democracy: ideology - politics - law (theoretical aspects)]. Chelyabinsk: Cheliab. gos. un-t, 2008, 255 p. [in Russian].

16. Ebzeev B. S., Krasnoryadtsev S. L., Levakin I. V., Radchenko I. V. Gosudarstvennoe edinstvo i tselostnost' Rossiiskoi Federatsii (konstitutsionno-pravovye problemy); otv. red. B. S. Ebzeev [State unity and integrity of the Russian Federation (constitutional problems). B.S. Ebzeev (Ed.)]. M.: ZAO «Izdatel'stvo «Ekonomika», 2005, 574 p. [in Russian].

17. Plekhanova L. N. Prezident Rossiiskoi Federatsii v sisteme organov pravovoi okhrany Konstitutsii Rossiiskoi 
Federatsii: dis. ... kand. iurid. nauk [President of Russia in the system of bodies of legal protection of the Constitution of the Russian Federation: Candidate's of Law thesis]. Tomsk, 2004, 261 p. [in Russian].

18. Ebzeev B. S. Konstitutsiia, vlast' i svoboda v Rossii: Opyt sinteticheskogo issledovaniia [Constitution, power and freedom in Russia: Experience of synthetical analyzing]. M.: Prospekt, 2014, 336 p. [in Russian].

19. Krasnov M. A. Personalistskii rezhim v Rossii: opyt institutsional'nogo analiza [Personalistic regime in Russia: experience of institutional analysis]. M.: Fond «Liberal'naia missiia», 2006, 180 p. [in Russian].

20. Krasnov M. A. Doktrina «podrazumevaemykh (skrytykh) polnomochii» glavy gosudarstva $\mathrm{v}$ rossiiskoi konstitutsionno-pravovoi praktike [The doctrine of the «implied (undetected) powers» of head of the state in Russian constitutional and legal practice]. Konstitutsionnyi vestnik, 2010, no. 2 (20) [in Russian].

21. Krasnov M. A. «Neitral'naia vlast'» B. Konstana i «Prezidentskii arbitrazh»Sh. De Gollia [«Neutral power» by B. Constant and «Presidential arbitration» by Ch. de Gaulle]. Gosudarstvo i pravo [State and Law], 2017, no. 6 [in Russian].

22. Kainov V. I. Institut prezidentstva: konstitutsionnopravovoi status: dis. ... d-ra iurid. nauk [Institute of the presidency: constitutional and legal status: Doctoral of Law thesis]. SPb., 1999, 332 p. [in Russian].

23. Poslanie Prezidenta Rossiiskoi Federatsii Federal'nomu Sobraniiu «Kakuiu Rossiiu my stroim» [Message of the President of the Russian Federation to the Federal Assembly «What kind of Russia do we built»]. Rossiiskaia gazeta, 2000, July 11 [in Russian].

24. Bespaly I. T., Polianskii V. V. Gosudarstvennoe pravo Rossiiskoi Federatsii: uchebnoe posobie: v $2 \mathrm{ch}$. Chast' II. 2-e izd., pererab. i dop. [State Law of the Russian Federation: in 2 parts. Part II. Federal Agency for Education. 2-nd edition, revised and enlarged]. Samara: Samarskii universitet, 2008, 539 p. [in Russian].

25. Sovremennye problemy organizatsii publichnoi vlasti. Monografiia. Ruk. avtorskogo koll. i otv. redaktor - professor S. A. Avak'ian [Contemporary problems of organizing of public authority. Monograph. Leader of the writing team and responsible editor - professor Avakyan S. A.]. M.: Iustitsinform, 2014, 596 p. [in Russian].

26. O chrezvychainom polozhenii: federal'nyi konstitutsionnyi zakon ot 30.05.2001 № 3-FKZ [On the state of emergency: federal Constitutional Law dated 30.05.2001 № 3-FKZ]. Sobranie zakonodatel'stva Rossiiskoi Federatsii [Collected Legislation of the Russian Federation], 2001, no. 23, Article 2277 [in Russian].

27. O gosudarstvennom gimne Rossiiskoi Federatsii: federal'nyi konstitutsionnyi zakon ot 25.12.2000 № 3-FKZ [On the national anthem of the Russian Federation: federal Constitutional Law dated 25.12.2000 № 3-FKZ]. Sobranie zakonodatel'stva Rossiiskoi Federatsii [Collected Legislation of the Russian Federation], 2000, no. 52 (part I), Article 5022 [in Russian].

28. Akkaeva Kh. A. Printsip razdeleniia vlasti konstitutsionnaia osnova postroeniia i funktsionirovaniia gosudarstvennogo mekhanizma v Rossii: dis. ... kand. iurid. nauk [Principle of the division of power - constitutional base of forming and functioning of state mechanism in Russia: Candidate's of Law thesis]. SPb., 2005, 196 p. [in Russian].

29. Gadzhi-Zade E. A. Konstitutsionnye modeli formy pravleniia i institut prezidentstva $v$ stranakh SNG: dis. ... kand. iurid. nauk [Constitutional models of the forms of government and the institute of presidency in CIS countries: Candidate's of Law thesis]. Volgograd, 2005, 227 p. [in Russian].

30. Okunkov L. A. Prezident i Pravitel'stvo (v mekhanizme gosudarstvennoi vlasti) [President and Government (in the mechanism of state power)]. Zhurnal rossiiskogo prava [Journal of Russian Law], 2001, no. 2 [in Russian].

31. Boldureva R. S. Razdelenie vlastei: teoretikopravovye aspekty: dis. ... kand. iurid. nauk [Division of powers: theoretical and legal aspects: Candidate's of Law thesis]. M., 1998, 164 p. [in Russian].

32. Krasnov M. A. Iskazhenie smysla rossiiskoi Konstitutsii - sledstvie nesbalansirovannoi sistemy vlasti [Distortion of a meaning of the Constitution of Russia is a result of the unbalanced system of power]. In: Konstitutsionnoe pravo i politika: sbornik materialov mezhdunarodnoi nauchnoi konferentsii: Iuridicheskii fakul'tet MGU imeni M.V. Lomonosova. 28-30 marta 2012 goda. Otv. red. prof. S. A. Avak'ian [Constitutional law and politics: collection of materials of the international scientific conference: Faculty of Law, Lomonosov Moscow State University. Lomonosov Moscow State University. March 28-30, 2012. S. A. Avakyan (Ed.)]. M.: Urist, 2012. $800 \mathrm{p}$.

33. Slovar' inostrannykh slov. 13 e izd., stereotip. [Dictionary of foreign words. 13th edition, stereotype]. M.: Rus. iaz., 1986, 736 p. [in Russian].

34. Postanovlenie Konstitutsionnogo Suda Rossiiskoi Federatsii ot 27.11.1999 № 2-P «Po delu o tolkovanii statei 71 (punkt «g»), 76 (chast' 1) i 112 (chast' 1) Konstitutsii Rossiiskoi Federatsii» [The decision of the Constitutional Court of the Russian Federation dated 27.11.1999 № 2-P «With regard to case of the interpretation of articles 71 (section «Г»), 76 (part 1) and 112 (part 1) of the Constitution of the Russian Federation»]. Sobranie zakonodatel'stva Rossiiskoi Federatsii [Collected Legislation of the Russian Federation], 1999, no. 6, Article 866 [in Russian].

35. Polozhenie o Ministerstve vnutrennikh del Rossiiskoi Federatsii, utverzhdennoe Ukazom Prezidenta Rossiiskoi Federatsii ot 21.12.2016 № 699 [Regulations on the Ministry of the Interior of the Russian Federation, approved by the Decree of the President of Russia dated 21.12.2016 № 699]. Sobranie zakonodatel'stva Rossiiskoi Federatsii [Collected Legislation of the Russian Federation], 2016, no. 52, Article 7614 [in Russian].

36. Polozheniia o Ministerstve iustitsii Rossiiskoi Federatsii, utverzhdennoe Ukazom Prezidenta Rossiiskoi Federatsii ot 13.10.2004 № 1313 [Regulations on the Ministry of Justice of the Russian Federation, approved by the Decree of the President of Russia dated 13.10.2004 № 1313]. Sobranie zakonodatel'stva Rossiiskoi Federatsii 
[Collected Legislation of the Russian Federation], 2004, no. 42, Article 4108 [in Russian].

37. Polozhenie o Ministerstve inostrannykh del Rossiiskoi Federatsii, utverzhdennoe Ukazom Prezidenta Rossiiskoi Federatsii ot 11.07.2004 № 865 [Regulations on the Ministry of Foreign Affairs, approved by the Decree of the President of Russia dated 11.07.2004 № 865]. Sobranie zakonodatel'stva Rossiiskoi Federatsii [Collected Legislation of the Russian Federation], 2004, no. 28, Article 2880 [in Russian].

38. Nudnenko L. A. Sistema ispolnitel'noi vlasti v Rossiiskoi Federatsii: problemy pravovoi reglamentatsii: monografiia [System of executive power in the Russian Federation: legal regulation problems: monograph]. M.: Iurlitinform, 2017, 320 p. [in Russian].

39. Ukaz Prezidenta Rossiiskoi Federatsii ot 05.04.2016 № 157 [Decree of the President of the Russian Federation dated 05.04.2016 № 157]. Rossiiskaia gazeta, 2016, April 7 [in Russian].

40. Pravitel'stvo Rossiiskoi Federatsii. Pod red. T. Ia. Khabrievoi [Government of the Russian Federation. T. Ya. Khabrieva (Ed.)]. M.: Norma, 2005, 608 p. [in Russian].

\section{FUNCTIONS OF THE PRESIDENTIAL POWER IN THE RUSSIAN FEDERATION}

In the article the functions of the President of Russia in the system of realization of public authority are observed and classification of those functions is offered. The author of the article distinguishes in the first place traditional representational function of the President of Russia, and secondly indicates the presence of specific functions of the head of the Russian country, connected with the coordination of public authorities and arbitration of public authorities in case of political conflicts. Thirdly, function of public administration that is realized by specific inherent presidential power methods, is observed. Meanwhile the author take an attempt to distinguish executive power and presidential power in the system of public administration. So that it is supposed that presidential power have an authority to moderate the executive power. The author of the article comes to the conclusion of the independent political and law nature of the functions of presidential power, that are not peculiar to the other branches of power.

Key words: state power, president of Russia, presidential power, functions of presidential power.

* Osetrov Sergey Anatolievich (sergey-lupus@mail.ru), Department of State and Administrative Law, Samara National Research University, 34, Moskovskoye shosse, Samara, 443086, Russian Federation. 